\title{
透析患者における血小板由来マイクロパーティクルの解析
}

\author{
岩田晶子安藤稔士 谷健三瓶宏 \\ 東京女子医科大学第 4 内科
}

key words：マイクロパーティクル，血栓症，フローサイトメトリー, Annexin V, P-selectin

〈要旨〉

慢性腎不全患者には，出血傾向を呈する一方で，血栓症に罹患する頻度も高率であるという，一見矛盾する2つ の病態が同居している。しかし光の原因については十分に検討されていない。これまでに，慢性腎不全患者の血小 板では， その表面の糖タンパク (GP IIb・IIIa) 発現の低下があること，光れと von Willebrand 因子との interaction の障害から血小板の血管内皮への粘着低下が生じることなどが指摘され，乥の出血傾向の機序はある程度解明され つつある。しかし，慢性腎不全の血栓形成性に対する血小板の関与については，報告が少ない。

我々は，病的血栓症の発症機序に血小板由来マイクロパーティクル (PMP) が少なからず関係していることを知 り，慢性腎不全患者が血栓を形成し易いことには，このPMP の暲常が関与しているのではないかとの仮説を立て た。 乥こで血液透析 (HD) 患者 22 例, 腹膜透析 (CAPD) 患者 15 例の血中 PMP 数と炎の質の変化をフローサイ トメトリ一を用いて，定量的に測定した。また，HD療法と内シャントのPMP 産生への影響についても検討を加え た。弚の結果，透析患者の血中PMP 数は，透析方法のいかんにかかわらず，健常コントロールより増加しており， 特に, Annexin V (凝固因子活性化能の指標), P-selectin (接着能の指標) を発現したPMP が有意に血中に増加 していることが判明した。またっこうしたPMP 数はHDとCAPD 間では差がなかった。4 時間のHD 治療の間に PMP 数の有意な増加はみられず，シャント血（内シャント近傍中枢側の脱血用静脈から採取した血液）と，非シャ ント血（非シャント肢の肘静脈から採取した血液）のPMP 数の間にも有意差はなかった。

以上より, 透析患者血中ではPMP 数が増加しており，このため血小板の正常止血機能が低下しているとされる透 析患者においても，血栓性疾患の罹患率は高いのであろう。また，PMP 数の増加には内シャントやHD治療過程の 血小板刺激は関与していないと推察された。

\section{Analysis of platelet-derived microparticle in dialysis patients}

Akiko Iwata, Minoru Ando, Ken Tsuchiya, Hiroshi Nihei

Department of Medicine IV, Tokyo Women's Medical University

Uremic patients have two opposite features in hemostatic status, that is, bleeding and thrombophilic tendency. Platelet functions for normal hemostasis are impaired, possibly contributing to the bleeding tendency in uremic patients. In contrast, platelet hyperaggregability and hypercoagulability that are commonly observed in uremic patients may be associated with their high incidence of thrombotic diseases. Recent studies suggested that platelet microparticles (PMPs) which are small vesicles with procoagulant activity released from the activated platelets might be relevant to thrombogenesis. This research investigated this hemostatic paradox in uremia by analyzing the characteristics of PMPs in circulation.

The subjects were patients under hemodialysis (HD) or continuous ambulatory peritoneal dialysis (CAPD), and healthy controls. The PMPs analysis was performed using a flow cytometer. The procoagulant and adhesive activities of PMPs were specially determined by their expressions of Annexin $V$ and P-selectin, respectively. The influence of HD procedure and arterio-venous (A-V) fistula on PMP formation were also assessed. The counts of total PMPs and PMPs with procoagulant and adhesive activities were statistically greater in both uremic groups, but those PMP counts did not differ between the uremic groups. The HD procedure and A-V fistula did

安藤＼cjkstart稔 東京都老人医療センター腎臟内科テ $173-0015$ 東京都板橋区栄町 35-2 (03-3964-1141)

Minoru Ando Fax 03-3964-1982

〔受付：平成 13 年 1 月 16 日，受理：平成 13 年 4 月 16 日〕 
not affect the PMP formation. In conclusion, the elevated PMP counts may be responsible for the thrombotic tendency in uremia despite impaired platelet function.

\section{緒言}

腎不全患者は出血傾向と易血栓症という一見矛盾す る出血凝固病態の異常を呈する。このことは, 䠦床統 計上で脳出血, 消化管出血とともに脳血栓, 心筋梗塞 などが透析患者の重要な死亡原因であることからも納 得される1).

一般に, 出血凝固過程, 血栓症発症のメカニズムで 主役的役割を果たしているのは血小板である。事実， これまでに腎不全（透析）患者では各種刺激下におい て，正常な止血血栓形成に不可欠な血小板表面の糖蛋 白の発現が低下していることが示されている ${ }^{21}$. また 一方で血小板凝集能の六進を旺すること光も示されて いるなど，まだ血小板の性質変化，機能の異常につい ては十分に解明されていない段階である。そこで我々 は，腎不全患者に招ける相反するかのような出血凝固 系の異常が生じる機序の一端を説明するため，血栓止 血学の分野で近年注日を集め, 徐々にその役割が解明 されつつある血小板由来マイクロパーティクル (PMP) の関与に着目した。

PMP は，血小板が活性化される際に放出される血 小板細胞膜の一部であり，その表面には活性化血小板 同様リン脂質や各種の接着分子が存在し, 凝固因子活 性化（procoagulant activity）作用を有すること市，血 流にのって遠隔的に白血球や内皮細胞に接着して自己 の持つ脂筫化学伝達物筫（PAF，アラキドン酸など） をそれらの細胞に提供 (chemical mediator delivery system）している可能性 5 などが指摘されている。 た，PMPは，いわゆる“ずり応力”による物理的刺激 により血小板からよく放出されることが証明されてお り, 病的血栓症発症のメカニズムとの深い関係が推察 されている ${ }^{6)}$. 臨床的には, 脳血管障害, 念性心筋梗塞, 不安定狭心症, 糖尿病などでその血中レベルが高いこ とが示されている ルシウム代謝などの異常を伴い, 種々の尿毒素の共存 する末期腎不全（透析）患者に扔いては，たと血小 板の正常止血機能は低下しているとしても，PMP の 量的・質的異常が存在することにより病的血栓症のリ スクが高まるのではないかとの仮説を立てた，そこで, 本研究では安定した非糖尿病性血液透析 (HD) 患者, 持続携行式腹膜透析 (CAPD) 患者を対象に，これらの 患者血中の PMP の量的・質的違いの有無を健常コン
表 1 透析患者の臨床像

\begin{tabular}{|c|c|c|}
\hline & $\begin{array}{c}\mathrm{HD} \text { 患者 } \\
(\mathrm{n}=22)\end{array}$ & $\begin{array}{c}\text { CAPD 患者 } \\
(\mathrm{n}=15)\end{array}$ \\
\hline 年齢（歳） & $48 \pm 12$ & $48 \pm 7.6$ \\
\hline 透析年数 (年) & $11 \pm 6.6$ & $5.4 \pm 3.9^{*}$ \\
\hline rHuEPO 療法 & 全例施行 & 全例施行 \\
\hline 抗血小板療法 & 全例末施行 & 全例未施行 \\
\hline ヘマトクリット（\%) & $31.2 \pm 4.1$ & $28.8 \pm 3.6$ \\
\hline 血小板数 $\left(\times 10^{9} / \mathrm{L}\right)$ & $164 \pm 54.3$ & $193 \pm 33.5^{*}$ \\
\hline 血清アルブミン值 $(\mathrm{g} / \mathrm{d} l)$ & $3.4 \pm 0.82$ & $3.1 \pm 1.4$ \\
\hline 血清尿素窒素値 $(m g / d ~ l)$ & $74.1 \pm 10.4$ & $59.9 \pm 8.7^{*}$ \\
\hline 血清クレアチニン値 $(\mathrm{mg} / \mathrm{d} l)$ & $11.1 \pm 3.7$ & $9.9 \pm 3.8$ \\
\hline
\end{tabular}

数值は平均值士標準偏差で表示.

$* p<0.05$ vs HD 患者

トロールと比較検討した。 PMP の測定はフローサイ トメトリー法により定量的に行った ${ }^{1 i}$.また, 特に臨床 的に重要と思われる PMP の持つ凝固因子活性化能 (procoagulant activity) と接着活性の程度について は，それぞれ Annexin V抢よび P-selectin (CD62P) の発現量で評価した ${ }^{12)}$.

\section{I. 対象および方法}

\section{1. 対 象}

慢性腎不全状態とPMP との関係を明らかにするた め, 本研究では糖尿病を有さず抗血小板療法を施行さ れていない外来通院中の安定したHD患者 22 名（ポ リスルフォン膜使用 14 名, PMMA 膜使用 4 名, セル ロース・トリアセテート膜使用 4 名), CAPD 患者 15 名（全例バクスター社システムII 使用），健常成人 17 名の血中 PMP 数を調べた，遺伝子組換え型エリスロ ポエチン ( $\mathrm{rHuEPO}$ ) 療法は全症例に施行されていた。 対象患者の臨床的特徵を表 1 にまとめたが, 健常コン

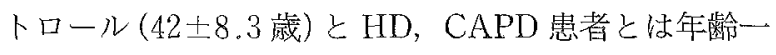
致していた。本研究施行前に全対象から informed consent 得た。

\section{2. 方 法}

血液サンプリングは HD 患者では各週の初回透析 開始時に内シャント（動静脈吻合）血管の返血用静脈 から採取し，CAPD 患者では外来受診日に肘部静脈か ら採取した。全血 $2 \mathrm{~m} l$ を $200 \mu l$ のEDTA-ACD 液を 含む真空採血管に採取し, 通常通り, 多血小板血漿 (PRP) を調整 ( $180 \mathrm{~g}$ で 20 分間, 室温遠心) した。 15 $\mu l$ の PRPを $0.1 \% \mathrm{EDTA}$ 生理的食塩液で $50 \mu l$ に希 

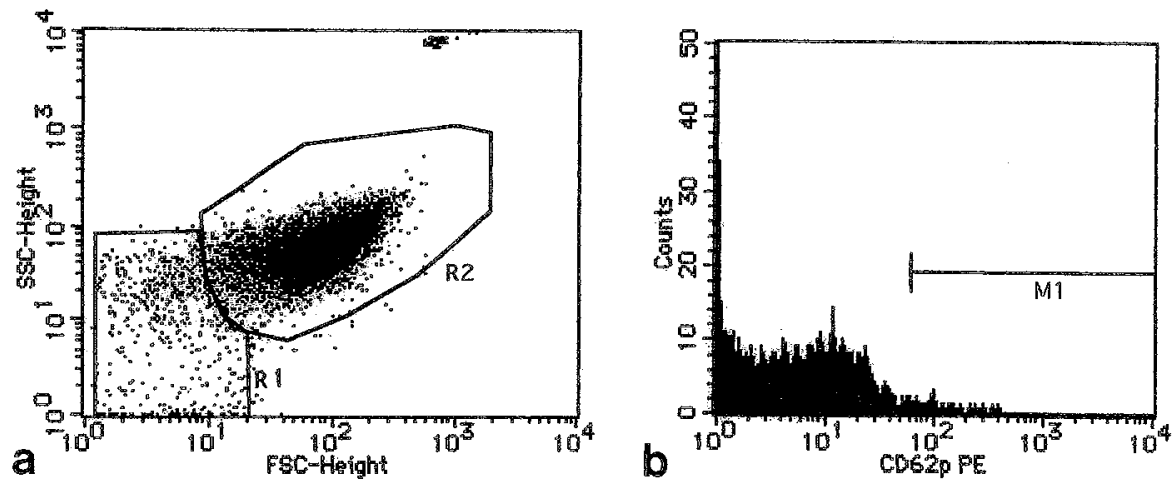

図 $1 \mathrm{a}$ ：GPIb 抗体陽性細胞を FSC-SSC 画面に展開したフローサイトメト リ一図。下方の細胞集団 (R1) が PMP，它の上の細胞集団(R2) は血小 板である。 b : 上記 PMP 細胞群の P-selectin の陽性率を示すヒストグ ラム。図中のバー（M1）の部分が陽性部分である（M1より左方のヒス トグラムはバックグラウンドレベルである).

釈した後, FITC-GPIb おょびPE-Annexin Vまたは PE-P-selectin (CD62P) 抗体 (各 $2 \mu l$ ) と暗所で室温 下に 30 分間インキュベートした後, フローサイトメー ター（FACS Calibur, Becton Dickenson 社）にかけ, 解析ソフト CellQuest (Becton Dickenson) により解 析した。まず血小板およびPMP を認識する特異抗体 であるFITC-GPIb でラベルされた細胞を Side light scatter (SSC)-Fluorescence-1（FL 1) 画面上でゲー トし，その細胞集団を Forward light scatter (FSC) SSC 画面に展開することで，PMP の細胞集団と血小 板の細胞集団を細胞サイズにより区別した（図１ａ）。 次に,このPMP の細胞集団の総数とその Annexin V または CD62P 陽性率を七ストグラム（図 1 b) から求 めた。 Annexin V拉よび P-selectin 陽性 PMP の絶対 数は, 総 PMP 数にそ机らの陽性率(\%)を掛け 100 で 除した值として求めた。測定值の定量化のため,フロー サイトメーター測定時にあらかじめサンプル内に 30000 個のラテックスビーズ (SPHERO Fluorescent Particles, 0.7〜0.9 $\mu \mathrm{m})$ を混和しておき，各サンプル 解析時間をフローサイトメーターが，ラテックスビー ズを 300 個吸引する時間に一定化した ${ }^{11)}$ 。抗FITCGPIb 抗体 ${ }^{13)}$ は野村昌作博士 (関西医科大学) のご好意 により供与されたものを用い，PE-Annexin Vは Pharmingen 社加ら, PE-CD62P Beckton Dickenson 社から購入した。

\section{III. 結 果}

\section{1，透析患者の血中 PMP 数}

HD 患者, CAPD 患者, 健常コントロールの血中総 PMP, Annexin V陽性 PMP, P-selectin 陽性 PMP 数を図 2 に示した。血中総 PMP 数, Annexin V 陽性
PMP おょひび P-selectin 陽性 PMP 数は, HD, CAPD いずれの透析患者においてもコントロールと比べ有意 に高值を呈した。特に, Annexin V陽性 PMP は, HD 群で高值であり, P-selectin 陽性 PMP 数は CAPD 群 で高值であった。しかし，HD と CAPD間ではいずれ の PMP 数とも有意差はなかった， HD, CAPD，コン トロールいずれの群に抢いても総 PMP, Annexin V 陽性 PMP, P-selectin 陽性 PMP 数の間には，乥れぞ れ相互治強い有意相関関係があった，HDの結果を図 3 亿示した。血小板数は, いずれの対象群においても総 PMP, Annexin PMP, P-selectin PMP 数と有意な 相関関係を持たなかった。

\section{HD 療法中の血小板数と総 PMP 数の变化}

$\mathrm{HD}$ 療法が血中 PMP 数の増加汇影響を及涩すかを 知るために, HD 中の血小板数と総 PMP 数を $\mathrm{HD}$ 開 始直前, 開始後 5 分, 30 分, 1 時間, 2 時間, 4 時間の 6 ポイントで測定し, 結果を表 2 に示した。検討した 3 症例のうち 2 症例はポリスルフォン膜のダイアライ ザー(フレゼニウス川澄株式会社), 1 症例は PMMA 膜のダイアライザー（東レ株式会社）が用いられてお り, 抗凝固㓮としてヘパリンが時間あたり 600〜800 単 位で持続注入されていた，血液サンプリングはすべて シャント血管の脱血側を用いた， 4 時間の $\mathrm{HD}$ 療法中 には，血小板数も総 PMP 数も有意な増減を示さな かった。

3. HD 患者におけるシャント血と非シャント血での 総 PMP 数の比較

4 例の HD 患者で内シャント脱血用血管（吻合部近 傍部）からサンプリングした血液と非シャント肢肘静 脈よりサンプリングした血液の総 PMP 数を測定し, 内シャントのPMP 産生に及方す影響を検討した。 シャント血液の総 PMP 数は, $4544 \pm 1290$, 非シャント 

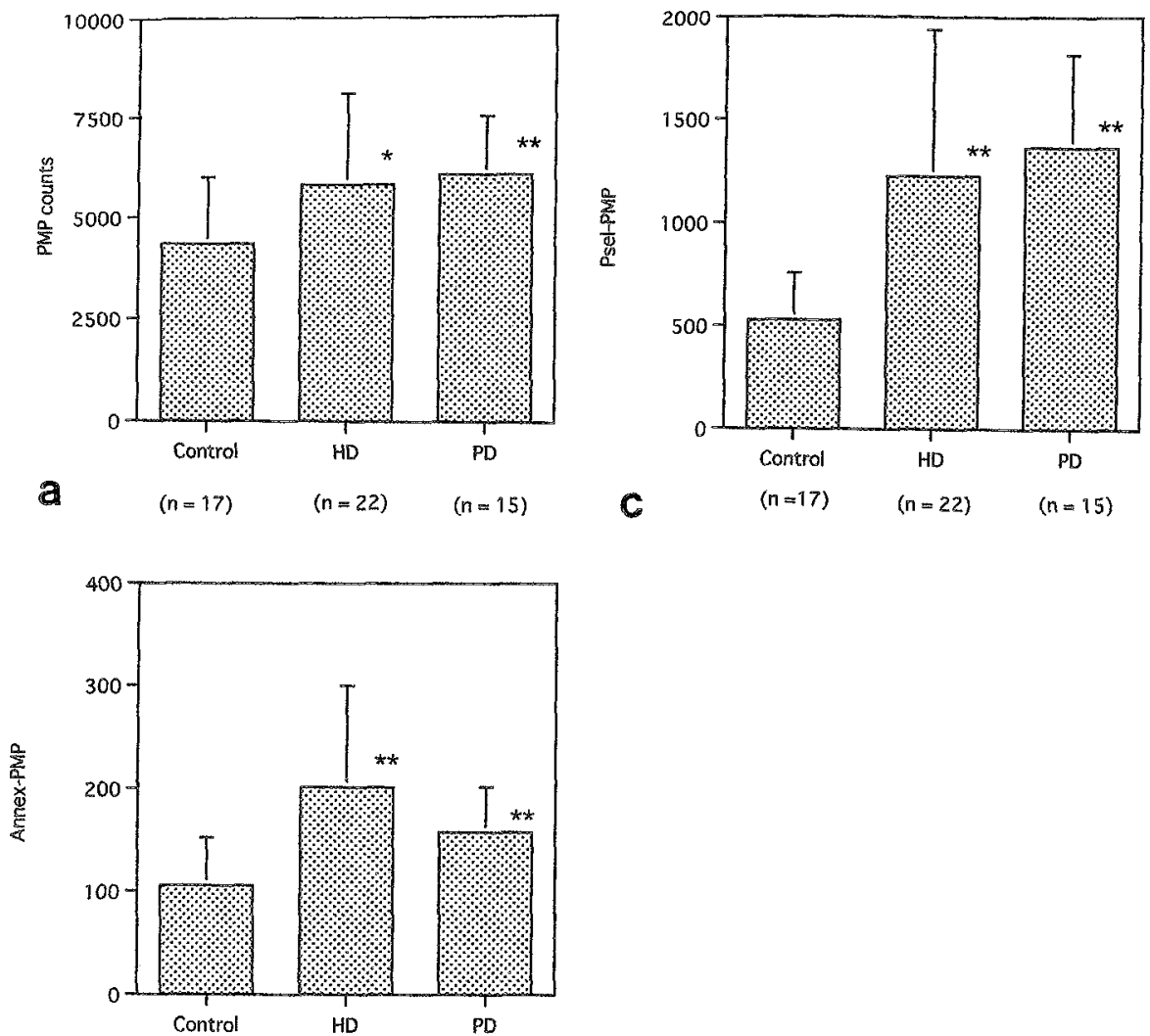

b $\quad(n=17) \quad(n=22) \quad(n=15)$

図 $2 \mathrm{a}$ : HD, CAPD, 健常コントロールの総 PMP 数の比較.

$\mathrm{b}$ ：HD, CAPD, 健常コントロールの Annexin-V 陽性 PMP 数の比較.

c : HD, CAPD, 健常コントロールの $\mathrm{P}^{-}$selectin 陽性 PMP 数の比較.

${ }^{*} \mathrm{p}<0.05$ vS コントロール

$* * p<0.01$ vs コントロール

表 2 血液透析中の血小板数と PMP 数の変化

\begin{tabular}{lcccccc}
\hline & 透析前 & 透析後 5 分 & 透析後 30 分 & 透析後 1 時間 & 透析後 2 時間 & 透析後 4 時間 \\
\hline 血小板数 $\times 10^{9} / \mathrm{L} \quad(\mathrm{n}=3)$ & $228 \pm 41.4$ & $249 \pm 61.2$ & $217 \pm 44.7$ & $219 \pm 41.7$ & $253 \pm 50.6$ & $240 \pm 42.9$ \\
$\mathrm{PMP}$ 数 $(\mathrm{n}=3)$ & $6186 \pm 524.7$ & $5399 \pm 809.0$ & $6860 \pm 1091$ & $6112 \pm 580.7$ & $7815 \pm 774.8$ & $6692 \pm 517.3$ \\
\hline
\end{tabular}

数値は平均值土標準誤差で表示。

血液の総 PMP 数は $4228.5 \pm 839.1$ であり，両者間に 注，有意な差はなかった。

\section{III. 考 案}

本研究結果から, 非糖尿病性の透析患者では, HD, CAPD の modality (透析方法)にかか放らず，血中に は Annexin Vおよび P-selectin 陽性の PMPがコン トロールに比して有意に増加していることが判明し た。換言すれば，透析患者の血液は，PMPという凝固 因子活性化能や接着活性の高い血栓形成誘導性に富む 微粒子を多く含んでいるということである，また，治 療過程で血小板を刺激する可能性を持つHD療法や 内シャントの存在は，こうしたPMP 産生には関与が
薄いことも明らかになった。

PMP の持つ瀶床的意義については，集積された データが不十分であり，末だ確定的なものはない。し かし，これまでに，血中 PMP 数が糖尿病患者, 急性心 筋梗塞患者, 不安定狭心症患者, 脳血管障害の患者な どで上昇していることが示され，PMPがこうした血 栓性疾患の発症機序に少なからず関与している可能 性，または血栓症のリスクファクターの一つであると する見解が有力である ${ }^{7 \sim 10)}$. Nomura ら ${ }^{14)}$ は, 論文の一 部分として腎不全患者に拈いて血中 PMP 数（本論文 の総 PMP 数に当るもの）が増加していることを報告 しているが，対象とした腎不全患者の詳細，例えば， 糖尿病患者含有率や抗血小板薬使用の有無，維持透析 患者をどの程度含んでいたのか，またその modality 


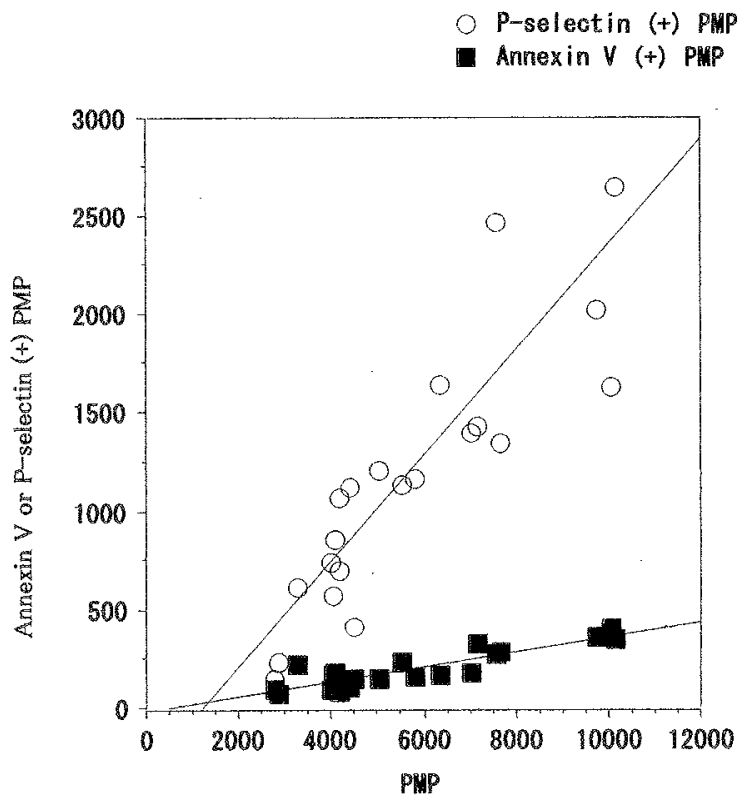

図 3 血液透析患者に招ける, PMP, Annexin V 陽性 PMP, P-selectin 陽性 PMP の相関関 係. PMP と Annexin V 陽性 PMP : $\mathrm{r}=$ $0.884, \mathrm{p}<0.001, \mathrm{PMP}$ と $\mathrm{P}-$ selectin 陽性 PMP : $\mathrm{r}=0.862, \mathrm{p}<0.001$

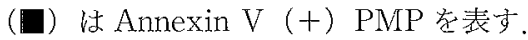

（○）は P-selectin（十）PMP を表す.

などが不明である。彼らも別の論文で明らかにしてい るように, 糖尿病自体の病態 ${ }^{15}$ や抗血小板薬 (特にシ口 スタゾールなど）の使用は血中 PMP 数に影響する ${ }^{16)}$ ことからも，本論文のデータは，対象の設定が明確で あり,より信頼性に優る慢性腎不全患者に晾数 PMPの情報を提供できたと考える。

次に，なぜ透析患者では PMP 数が増加しているか の疑問に若干の検討を加光た。近年の in vitro 実験加 ら“ずり応力”が PMP 産生の強い刺激になりうること が知られている6)。そこで，とりあえず検証すべき点と して次の 2 つを取りあげた。

（1）HD療法中に血小板に加わると思われる物理的 刺激が人工心肺施行時 ${ }^{17)}$ と同様に血中 PMP 数の増加 に寄与しているか，(2) 内シャントを通過する際の刺 激が同様に HD 患者の慢性的 PMP 産生刺激になっ

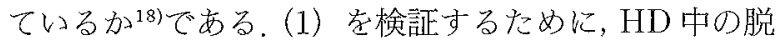
血側（ダイアライザー前）から血液をサンプリングし, 開始㨁後を含めて HD 終了まで経時的に PMP 数を カウントしたところ, 少なくとも HD 直後 (4 時間) の 時点までは, 患者体内の PMP 数の有意な上昇はなく, $\mathrm{HD}$ 療法そのものが患者流血中の PMP 数に影響を与 えていた可能性は低い. 今回はダイアライザー前後で のPMP 数の変化については検討していないが，少な くとも図 2 に示した HD患者の定常的な血中 PMP
数の増加に HD 療法が関係していた可能性は低い。 こ の点で, 人工心肺と HD 療法では PMP 産生にかかわ る血小板刺激の質およびその程度は異なるものと思わ れる。また, $\mathrm{HD}$ と CAPD 患者間で総 PMP 数, Annexin $\mathrm{V}, \mathrm{P}-$ selectin 陽性 PMP 数のいずれにも差が ないことから長期的にも HD 治療そのものが PMP 産生に影響している可能性は否定的である。さらに, HD 療法中, 特に開始 30 分頃に血小板数が有意に減少

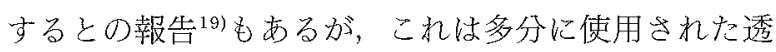
析膜の材質の性状に関わるもののようである。本実験 中血小板数にその傾向は認められておらず，使用され たダイアライザー膜(ポリスルフォン膜と PMMA 膜) の性状が少なからず関係していたことは否定できな い. 血小板数同様に使用透析膜と HD 中 PMP 数の変 動についても症例数を増やして詳しく検討を加える必 要があると考えられる。（2）に関しては，シャント血 液, 非シャント血液の含有する総 PMP 数に変化のな いこと，HD 患者と CAPD 患者 (全例とも動静脈吻合 を有していない) 間で PMP 数に差がないことからも 内シャントが透析患者の PMP 産生に影響している可 能性も低いと思わ礼る。

以上，今回の検討から，透析患者(慢性腎不全患者) における PMP 数の増加に, 尿毒症の複雑な病態その ものが関係している可能性が高いと考えられるが，今 回の対象患者は全例 rHuEPO 補充療法を受けてお り，血小板産生と活性を刺激することが知られる $\mathrm{rHuEPO}^{20)}$ が透析患者の PMP 増加に関与した可能性 は否定できない。この件は，今後に残された重要な検 討課題の一つであろう。現時点では, in vivoでの PMP 産生刺激因子の検討は血液病学, 血栓止血学の 分野でも十分には行われておらずこれ以上の推論は差 し控元, 今後の PMP 研究の発展に期待したい。

\section{結語}

透析患者では，軽度の血小板減少を呈する21)ことに 加え, 止血に必要な血小板機能は低下しており出血傾 向を呈し易い ${ }^{22,23)}$. 一方で, PMP という血秷形成性粒 子が透析患者の流血中に増加しており，これが透析患 者に高頻度にみられる動脈血栓症の発症に少なからず 関係している可能性がある。こうして, 透析患者は出 血と血栓傾向という一見矛盾する病態を併せ持つこと になる可能性が推測される。

謝辞：フローサイトメトリ一検査での技術的ご協力を 頂いた大塚製薬第一創薬研究所, 小関 靖氏に深謝致し 
まず。

\section{文献}

1）日本透析医学会統計調査委員会：わが国の慢性透析療 法の現況（1998 年 12 月 31 日現在）。 p 105, 日本透析 医学会，1999

2) Gawaz M, Dobos G, Spath M, Schollmeyer P, Gurland HJ, Mujais SK : Impaired function of platelet membrane glycoprotein II b-IIIa in end-stage renal diseases. J Am Soc Nephrol 5:36-46, 1994

3) Viener AM, Aviram M, Better OS, Brook JR: Enhanced in vitro Platelet aggregation in hemodialysis patients. Nephron $43: 139-143,1986$

4) Sims PJ, Faioni EM, Wiedmer T, Shattil SJ : Complement proteins C5b-9 cause release of membrane vesicles from the platelet surface that are enriched in the membrane receptor for coagulation factor $\mathrm{Va}$ and express prothrombinase activity. J Biol Chem $263: 18205-18212,1988$

5) Iwamoto S, Kawasaki T, Kambayashi J, Ariyoshi $\mathrm{H}$, Monden $\mathrm{M}$ : Platelet microparticles : a carrier of platelet-activating factor? Biophys Res Commun 218:940-944, 1996

6) Miyazaki $Y$, Nomura S, Miyake T, Kagawa H, Kitada C, Taniguchi H, Komiyama Y, Fujimura Y, Ikeda Y, Fukuhara S: High shear stress can initiate both platelet aggregation and shedding of procoagulant containing microparticles. Blood 88 : 3456-3464, 1996

7) Geiser T, Sturzenegger M, Genewein U, Haeberli A, Beer JH : Mechanisms of cerebrovascular events as assessed by procoagulant activity, cerebral microemboli, and platelet microparticles in patients with prosthetic heart valves. Stroke $29: 1770-1777$, 1998

8) Gawaz M, Neumann JF, Ott I, Schiessler A, Schomig A : Platelet function in acute myocardial infarction treated with direct angioplasty. Circulation $93: 229-237,1996$

9) Singh N, Gemell CH, Daly PA, Yeo EL : Elevated platelet-derived microparticle levels during unstable angina. Can J Cardiol 11 : 1015-1021, 1995

10) Nomura S, Suzuki M, Katsura K, Xie GL, Miyazaki Y, Miyake T, Kido H, Kagawa H, Fukuhara S: Platelet-derived microparticles may influence the development of atherosclerosis in diabetes mellitus. Atherosclerosis 116 : 235-240, 1995

11) Combes V, Dignat-George F, Mutin M, Sampol J : A new flow cytometry method of platelet-derived microparticle quantitation in plasma. Thrombosis and Haemostasis $7: 212-224,1997$

12) Dachary-Prigent J, Freyssinet J-M, Pasquet J-M, Carron $\mathrm{J}-\mathrm{C}$, Nurden $\mathrm{AT}$ : Annexin $\mathrm{V}$ as a probe of aminophospholipid exposure and platelet membrane vesiculation: A flow cytometry study showing a role for free sulfhydryl groups. Blood 81 :25542565, 1993

13) Yanabu M, Ozaki Y, Nomura S, Miyake T, Miyazaki Y, Kagawa H, Yamanaka Y, Asazuma N, Satoh K, Kume S, Komiyama Y, Fukuhara S: Tyrosine phosphorylation and $\mathrm{p} 72^{\mathrm{syk}}$ activation by an antiglycoprotein Ib monoclonal antibody. Blood 89: 1590-1598, 1997

14) Nomura S, Shouzu A, Nishikawa M, Kokawa T, Yasunaga $\mathrm{K}$ : Significance of platelet-derived microparticles in uremia. Nephron 63:485, 1993

15) Nomura S, Komiyama $Y$, Miyake $T$, Miyazaki $Y$, Kido H, Suzuki M, Kagawa H, Yanabu M, Takahashi $\mathrm{H}$, Fukuhara $\mathrm{S}$ : Amyloid $\beta$-protein precursorrich platelet microparticles in thrombotic disease. Thrombosis and Haemostasis $72: 519-522,1994$

16) Nomura S, Shouzu A, Omoto S, Hayakawa $T$, Kagawa $H$, Nishikawa M, Inada M, Fujimura $Y$, Ikeda Y, Fukuhara S: Effect of cilostazol on soluble adhesion molecules and platelet-derived microparticles in patients with diabetes. Thromb Haemost 88:388-392, 1998

17) Miyamoto S, Marcinkiewicz C, Henry Edmunds L Jr, Niewiarowski S: Measurement of platelet microparticles during cardiopulmonary bypass by means of captured ELISA for GPIIb/IIIa. Thromb Haemost 80 : 225-230, 1998

18) Ben Driss A, Benessiano J, Poitevin P, Levy BI, Michel JB: Arterial expansive remodeling induced by high flow rates. Am J Physiol 272: H 851-H 858, 1997

19）新井浩之, 松崎竜児, 矢吹菛希子, 難波香織, 三浦 明, 杉浦清史, 小篠 榮, 鈴木利明：HPM 型ビタミン E 固 定化再生セルロース膜 (CLEE15N) の生体適合性およ び性能評洒。篎と透析 40 別冊ハイパフォーマンスメン ブレン'96:118-122，1996

20) Stohlawetz PJ, Dzirlo L, Hergovich N, Lackner E, Mensik C, Eichler HG, Kabrna E, Geissler K, Jilma $B$ : Effects of erythropoietin on platelet reactivity and thrombopoiesis in humans. Blood 95:29832989,2000

21）岩本祐介, 安藤 稔, 土谷 健, 二瓶 宏: 透析患者 の血小板減少症の解析．日腎会誌 $41: 712-718,1999$

22) Remuzzi $G$ : Bleeding in renal failure. Lancet 1 : 1205-1208, 1988

23) Escolar G, Cases A, Bastida E, Garrido M, Lopez J, Revert L, Castillo R, Ordinas A : Uremic platelets have a functional defect affecting the interaction of von Willebrand factor with glycoprotein IIb-IIIa. Blood 76 : 1336-1340, 1990 